\title{
Squamous cell carcinoma of the footpad with systemic metastasis in a captive crowned solitary eagle (Buteogallus coronatus)
}

\author{
Camila Maria da Silva ROCHA ${ }^{1}$, Tais Meziara WILSON ${ }^{1}$, \\ Davi Emanuel Ribeiro de SOUSA ${ }^{1)}$, Alexandra Ariadne Bittencourt Gonçalves \\ PEREIRA ${ }^{1)}$, André Santos LEONARDO ${ }^{2)}$, Khesller Patrícia Olazia NAME ${ }^{3)}$ and \\ Márcio Botelho de CASTRO ${ }^{1) *}$
1)Veterinary Pathology Laboratory, Campus Darcy Ribeiro, University of Brasília, Brasília, DF 70910970, Brazil ${ }^{2)}$ Histopato-Análise Anatomopatológica Veterinária, SHIS QI 29, Brasília, DF 71675530, Brazil
${ }^{3)}$ Institute of Health Sciences, Coordination of Biological Sciences, Universidade Paulista, Brasília, DF 70390130, \\ Brazil
}

\section{J. Vet. Med. Sci. \\ 82(11): 1627-1630, 2020}

doi: 10.1292/jvms.20-0285

\section{Received: 18 May 2020}

Accepted: 25 August 2020

Advanced Epub:

9 September 2020

\begin{abstract}
Squamous cell carcinomas (SCC) are one of the most common tumors of the tegument that can have a misdiagnosis of chronic skin wounds. An adult captive crowned solitary eagle presented an indolent wound-like ulcer on the footpad and a fatal outcome. An infiltrating tumoral mass in the foot and multiple tumoral metastatic nodules in visceral organs were detected. The neoplasm was composed of atypical squamous cells with strong positivity for cytokeratin, "keratin pearl" structures, and marked invasion of tissues confirming a diagnosis of metastatic SCC. This might be the first report of an SSC with metastasis on the footpad in a captive Chaco eagle, which is one of the endangered species of birds of prey.
\end{abstract}

KEY WORDS: avian disease, birds of prey, cancer, Chaco eagle, immunohistochemistry

Birds of prey or raptors are majestic creatures that awaken admiration in human civilizations. Despite the ancient relationship between birds of prey and humans, information on diseases of raptors is still limited, creating a challenge to conservation, prevention, and therapeutics. The crowned solitary eagle, or Chaco eagle (Buteogallus coronatus), is an endangered species jeopardized by the fragmentation of environments and small populations and is of limited occurrence in areas of Argentina, Bolivia, Brazil, and Paraguay [20]. Raptors represent a substantial captive population of birds in zoos, avian collections, and falconry clubs. Neoplasms in this species are uncommon and are mainly reported in the northern hemisphere [6, 10-12]. Skin tumors in birds of prey are even rarer $[3,6,10]$. The constant improvements in care conditions, advances in avian medicine and therapeutics, and an increase in the longevity become neoplasms a relevant diagnosis in captive birds [11].

An adult female crowned solitary eagle (Buteogallus coronatus), $2.83 \mathrm{~kg}$ body weight, was a captive bird with a clinical diagnosis of bumblefoot. The ulcerative wound on the foot was cleaned daily, treated topically with antibiotics, and bandaging for three months. The wound-like ulcer was located on the center of the sole extending to the region between the middle and external toes of the left lower limb. Subsequently, a complete oblique closed fracture in the distal third of the left tibiotarsus was detected during the daily inspection of the enclosure in the veterinary facility of the zoo of Brasília, Brazil. The fracture reduction and immobilization were conducted with a bandage, and the eagle received fluid therapy and enteral nutrition. The next morning, the animal was prostrate and died in a few hours, and was taken for a necropsy.

Moderate swelling of the middle and external toes and an ulcerative wound of $5.0 \mathrm{~cm}$ diameter were observed at the skin of the footpad on the left lower limb. A longitudinal section of the left leg and foot showed a firm white tumoral mass of $7.0 \mathrm{~cm} \times 5.0$ $\mathrm{cm} \times 4.5 \mathrm{~cm}$ deeply infiltrated in most of the footpad and middle toe (Fig. 1). In the coelomic cavity, multiple white and rounded metastatic nodules ranging from $0.5-3.0 \mathrm{~cm}$ in diameter and with irregular surfaces were observed in the lungs, liver, spleen, oviducts, kidneys (Fig. 2A), air sacs, and adhered to the left sciatic nerve. There were also multifocal to coalescent white tumoral nodules on the pericardium (Fig. 2B) within an abundant yellow and viscous liquid, and neoplastic infiltration to the heart.

Samples of tissues and organs were collected, fixed in $10 \%$ buffered formalin with phosphates ( $\mathrm{pH} 7.0)$, embedded in paraffin, and sections of $4 \mu \mathrm{m}$ thick were stained with hematoxylin-eosin (H\&E). Immunohistochemistry was performed on tumor samples using the biotin-peroxidase-streptavidin method (ImmunoDetector DAB-HRP, BioSB Inc., Santa Barbara, CA, USA), and the 


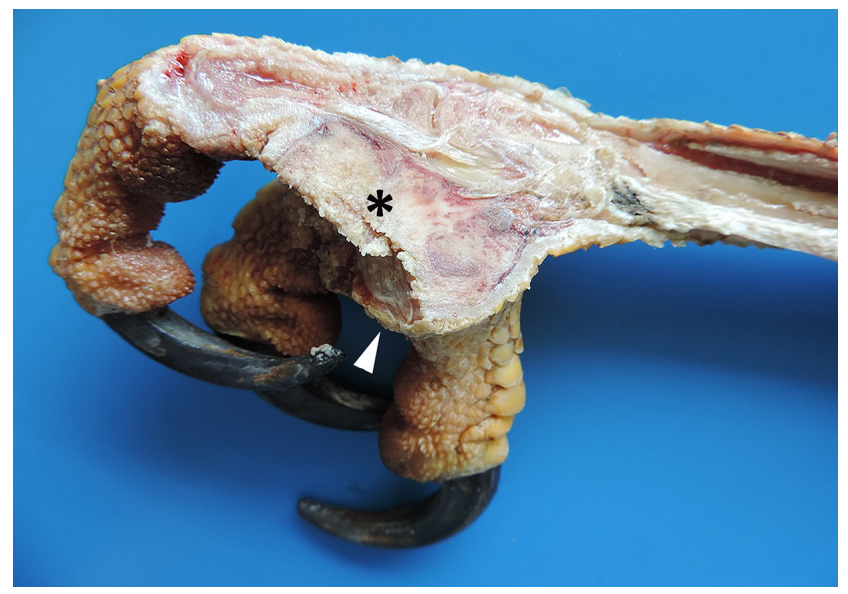

Fig. 1. Buteogallus coronatus, left foot. Squamous cell carcinoma (*). Ulcerative wound on the footpad with marked tumoral infiltration (arrowhead).
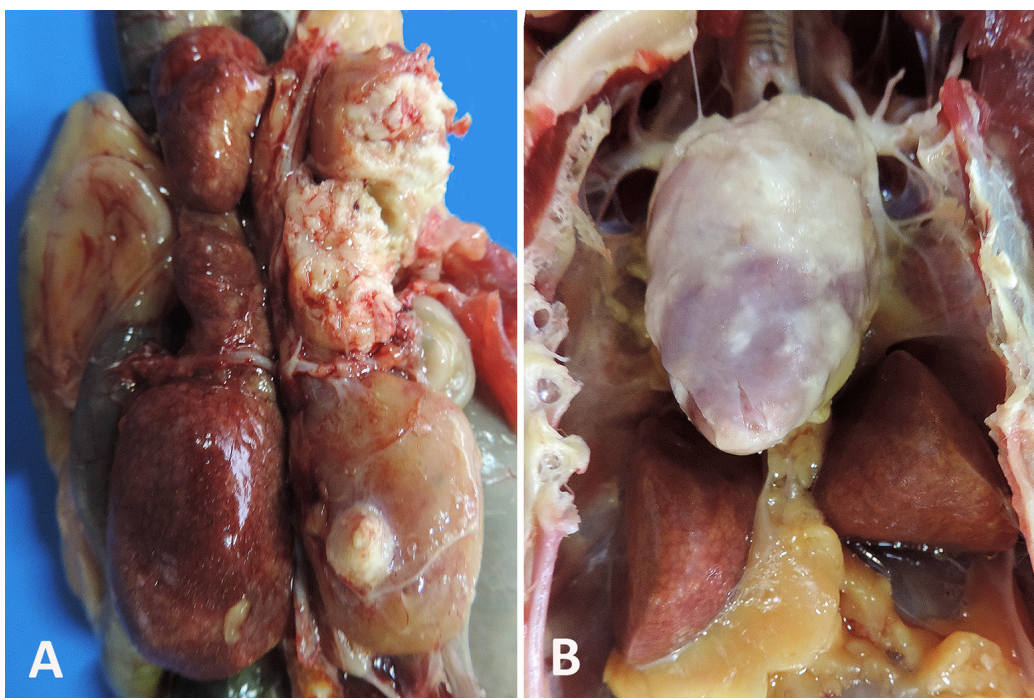

Fig. 2. Buteogallus coronatus. Squamous cell carcinoma. A) Multiple white and rounded metastatic nodules in the right kidney. B) Multifocal to coalescent white infiltrative masses in the pericardium.

primary antibodies against wide spectrum cytokeratin (polyclonal wide spectrum cytokeratin, Dako Corp., Santa Clara, CA, USA), dilution: 1:1,000, positive tissue control: canine squamous cell carcinoma, and vimentin (Vim3B4, Dako Corp.), dilution: 1:400, positive tissue control: normal dog skin. Primary antibodies were omitted on the tissue sections and used as negative controls.

Histologically, the left lower limb showed ulcerated epidermis, multifocal to coalescent cords and nests of moderately differentiated neoplastic squamous cells with abundant eosinophilic cytoplasm, and forming numerous "keratin pearl" structures composed of compact and concentric laminated keratin deeply infiltrated to the connective tissues (Fig. 3A). Tumor cells presented moderate anisocytosis, coarse chromatin, single to multiple nucleoli, and 2-3 figures of mitosis per high-power field. There was moderate fibrosis and mild inflammatory infiltrates of heterophils surrounding the neoplasm in the footpad. Multifocal to coalescent metastatic nests and cords of neoplastic squamous cells and "keratin pearls", vascular invasion, and tumor emboli were detected in the kidneys, liver, lungs, spleen, oviducts, air sacs, and infiltrating the sciatic nerves. Heart and pericardium also had multifocal metastasis and marked infiltration by neoplastic cells. Tumor cells within the ulcerated wound and metastatic foci in organs showed a strong cytokeratin cytoplasmic positivity (Fig. 3B) and negative vimentin immunostaining. No other significant gross or microscopic changes were observed in different organs and tissues, and tumoral infiltration was not detected in the fracture site or bone marrow. Gross and microscopic findings and the immunohistochemical assay were consistent with the diagnosis of metastatic squamous cell carcinoma (SCC) in the footpad of the eagle.

Pododermatitis or bumblefoot in raptors is characterized by indolent ulcers in severe cases and is considered a multifactorial, challenging, and difficult situation to treat $[17,18]$. The long-term topic therapy of ulcerated footpad wounds, as observed in the crowned solitary eagle, is a common condition in captive birds of prey with a clinical diagnosis of bumblefoot. Therefore, the 


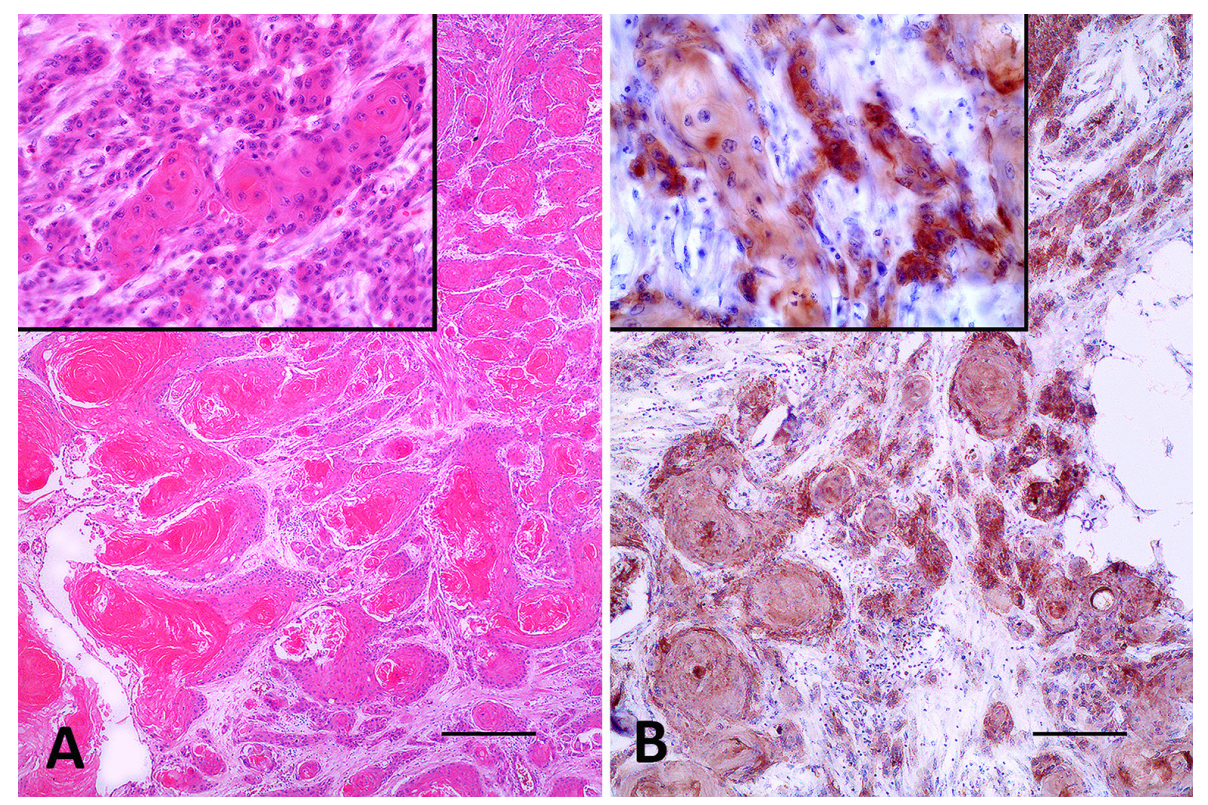

Fig. 3. Buteogallus coronatus. Squamous cell carcinoma. A) Ulcerated skin of the footpad. Neoplastic squamous cells are forming numerous "keratin pearls" and infiltrating the connective tissues deeply. Close view: Cords and nests of tumoral cells with moderate anisocytosis, coarse chromatin, and evident nucleoli. Hematoxylin and eosin. Bar $=250 \mu \mathrm{m}$. B) Heart. Cytokeratin immunostaining of metastatic squamous cells within the myocardium. Close view: Strong cytoplasmic cytokeratin immunolabeling of neoplastic cells. Immunoperoxidase, polyclonal wide spectrum cytokeratin antibody. Bar $=100 \mu \mathrm{m}$.

presentation of the wound-like ulcer of SCC on the footpad of the Chaco eagle led to the misleading clinical diagnosis of severe bumblefoot.

SCCs are one of the most prevalent skin tumors in birds $[6,11,16]$. The wound-like ulcer aspect is a common feature of SCCs in the skin of birds [1,9] and should be included in the differential diagnosis of integumental chronic ulcerated wounds [3, 4, $9,12]$. Despite the gross similarities between bumblefoot and ulcerated SCC, the unilateral distribution of lesion on the foot of the Chaco eagle should be considered in the clinical evaluation to avoid a wrong diagnosis, since most cases of bumblefoot are bilateral [17].

The tumor arising from the skin of the footpad, such as that detected in the captive Chaco eagle, is a unique presentation of SCCs in birds of prey. The most common body locations of SCCs in raptors include the flank, thigh, pre-femoral region, ventral aspect of the wing, and oral cavity [11, 15, 16]. Moreover, SCCs on the sole of feet are also rare in other birds [1, 14]. The skin of wings, body, legs, inguinal region, uropygial gland, cloaca, oropharynx, mucocutaneous junctions, and mucous membranes are the most frequent sites of SCCs in most bird species [9, 11, 12].

Metastases were remarkable in the organs within the coelomic cavity of the crowned solitary eagle with SCC in the footpad. Most skin SSCs are not metastatic in raptors [3,6]; however, metastases of an oral SCC has occurred in the lung and bones of a Montagu's harrier [15]. In general, SCCs are locally invasive, and metastases are rare in birds [11, 12]. SCCs of the foot reported in birds are locally invasive, but not metastatic, and may present local recurrence $[1,14]$. The limited information on skin tumors in birds of prey do not enable speculations as to the metastasis risk factors related to the SCC in the captive Chaco eagle.

The histological and immunohistochemical features of the metastatic SCC in the footpad and coelomic cavity organs of the eagle are similar to those observed in most animal species and man. A high grade of keratinization, invasiveness, tumor emboli, and metastization were the most relevant microscopic features observed in the SCC of the footpad. In birds, a variable degree of keratinization, invasion of the adjacent tissues, and metastasis have been reported in SCCs in different body locations [9, 11, 12, 16]. The cytoplasm of neoplastic cells in the footpad was strongly positive for cytokeratin (CK), a remarkable feature also observed in SCCs in the foot of a pink-backed pelican [14] and in the mandible of two psittacines [7].

The mitotic index (MI) detected in the tumor of the Chaco eagle was similar to those observed in a metastatic oral SCC in a Montagu's harrier [15], and also in non-metastatic SCCs in raptors, psittacines, and domestic fowl [9]. Therefore, MI is not a reliable criterion to differentiate metastatic from non-metastatic SCCs in birds. Studies to assess the cell cycle markers, MI, and the expression of tumor markers in avian neoplasms are still inceptive. Tumor and cell cycle markers seem to be reliable tools to detect an accurate $\mathrm{MI}$ and the differentiation between malignant and benign tumors $[8,9]$. The relationship between tumoral morphology, MI, aggressiveness, and metastasis in most avian species is still uncertain.

At first impression, the wound in the footpad was a clinical misdiagnosis of bumblefoot in the Chaco eagle. However, the wound-like ulcer also had moderate scarring and mild inflammation surrounding the infiltrative SCC. Therefore, it is possible to hypothesize that a long-term non-ulcerated bumblefoot or another chronic foot injury, not detected early, progressed to an SCC. 
Long-term and continuous tissue irritation in raptors [11] and inflammation and scarring in human beings and animals [2, 13, 19,

21] seems to trigger the progression of chronic skin injuries to SCCs.

Viral particles and the DNA of fowlpox and papillomavirus have been detected in avian SCCs. However, the role of viral infection in the tumorigenesis is not entirely determined in birds and broiler chicken [5, 9, 14]. Although we did not conduct viral detection in the tumor of the eagle, koilocytes, intranuclear inclusion bodies and cytoplasmic vacuolation typical of papillomavirus infection, and intracytoplasmic Bollinger's inclusion bodies of fowlpox were not detected.

The occurrence of SCCs on the feet of raptors is unknown. This first report of a metastatic SCC in the footpad of a captive crowned solitary eagle with a misdiagnosis of bumblefoot highlights the relevance of a proper clinical-pathological approach to chronic skin wounds. Skin biopsies and an adequate clinical investigation are essential for the correct diagnosis and therapy of neoplasms, indolent ulcerated bumblefoot, or other chronic injuries on the feet of birds of prey.

ACKNOWLEDGMENTS. Special thanks to Coordenação de Aperfeiçoamento de Pessoal de Nível Superior-Brazil (CAPES) for the partial financing (Finance Code 001), and the support of the National Council for Scientific and Technological Development (CNPQ).

\section{REFERENCES}

1. Abu, J., Wünschmann, A., Redig, P. T. and Feeney, D. 2009. Management of a cutaneous squamous cell carcinoma in an American flamingo (Phoenicopterus ruber). J. Avian Med. Surg. 23: 44-48. [Medline] [CrossRef]

2. Cocchetto, V., Magrin, P., de Paula, R. A., Aidé, M., Monte Razo, L. and Pantaleão, L. 2013. Squamous cell carcinoma in chronic wound: Marjolin ulcer. Dermatol. Online J. 19: 7. [Medline]

3. Cooper, J. E., Wilkens, W. and Lawrence, K. 1993. Four cases of neoplasia. pp. 32-33. In: Birds of Prey, Raptor Biomedicine (Redig, P. T., Cooper, J. E., Remple, J. D. and Hunter D. B. eds.), University of Minnesota Press, Minneapolis.

4. Cooper, J. E., Cooper, M. E., Krone, O., Newton, I., Peakall, D. B. and Zucca, P. 2002A. Foot conditions. pp. 121-131. In: Birds of Prey: Health \& Disease, 3rd ed. (Cooper, J. E. ed.), Blackwell Science, Oxford.

5. Fallavena, L. C. B., Canal, C. W., Salle, C. T., Moraes, H. L., Rocha, S. L., Pereira, R. A. and da Silva, A. B. 2002. Presence of avipoxvirus DNA in avian dermal squamous cell carcinoma. Avian Pathol. 31: 241-246. [Medline] [CrossRef]

6. Forbes, N. A., Cooper, J. E. and Higgins, R. J. 2000. Neoplasms of birds of prey. pp. 127-145. In: Raptor Biomedicine III (Lumeij, J. T., Remple, J. D., Redig, P. T., Lierz, M., and Cooper, J. E. eds.), Lake Worth: Zoological Education Network.

7. Halley, M. A., Stilwell, J. M., Comolli, J. R., Wilkinson, S. L., Reavill, D. R., Divers, S., Mayer, J. and Rissi, D. R. 2020. Mandibular squamous cell carcinoma in 2 psittacines. J. Vet. Diagn. Invest. 32: 344-347. [Medline] [CrossRef]

8. Jakab, C., Balka, G., Szabára, A., Csaba, C. and Pazár, P. 2013. A case of cutaneous angiolipoleiomyoma (angiomyolipoma) in a budgerigar (Melopsittacus undulatus). Avian Pathol. 42: 511-515. [Medline] [CrossRef]

9. Jones, A. L., Suárez-Bonnet, A., Mitchell, J. A., Ramirez, G. A., Stidworthy, M. F. and Priestnall, S. L. 2020. Avian Papilloma and Squamous Cell Carcinoma: a Histopathological, Immunohistochemical and Virological study. J. Comp. Pathol. 175: 13-23. [Medline] [CrossRef]

10. Jones, R. 2008. Raptors: systemic and non-infectious diseases. pp. 284-298. In: BSAVA Manual of Raptors, Pigeons and Passerine Birds (Chitty, J. and Lierz, M. eds.), British Small Animal Veterinary Association, Ontario.

11. Lightfoot, T. L. 2006. Overview of tumors: Clinical avian neoplasia and oncology. pp. 560-565. In: Clinical Avian Medicine, vol 2 (Lightfoot, T. L. and Harrison, G. J. eds), Spix Publishing, Palm Beach.

12. Nemeth, N. M., Gonzalez-Astudillo, V., Oesterle, P. T. and Howerth, E. W. 2016. A 5-year retrospective review of avian diseases diagnosed at the Department of Pathology, University of Georgia. J. Comp. Pathol. 155: 105-120. [Medline] [CrossRef]

13. O'Toole, D. and Fox, J. D. 2003. Chronic hyperplastic and neoplastic cutaneous lesions (Marjolin's ulcer) in hot-brand sites in adult beef cattle. J. Vet. Diagn. Invest. 15: 64-67. [Medline] [CrossRef]

14. Pesaro, S., Biancani, B., Fabbrizi, G. and Rossi, G. 2009. Squamous cell carcinoma with presence of poxvirus-like inclusions in the foot of a pinkbacked pelican (Pelecanus rufescens). Avian Pathol. 38: 229-231. [Medline] [CrossRef]

15. Ramis, A., Gibert, X., Majó, N. and Grifols, J. 1999. Metastatic oral squamous cell carcinoma in a Montagu's harrier (Circus pigargus). J. Vet. Diagn. Invest. 11: 191-194. [Medline] [CrossRef]

16. Reavill, D. R. 2004. Tumors of pet birds. Vet. Clin. North Am. Exot. Anim. Pract. 7: 537-560, v. [Medline] [CrossRef]

17. Remple, J. D. and Al-Ashbal, A. A. 2000. Raptor bumblefoot: another look at histopathology and pathogenesis. pp. 92-98. In: Raptor Biomedicine III (Lumeij, J. T., Remple, J. D., Redig, P. T., Lierz, M. and Cooper, J. E. eds.), Zoological Education Network, Lake Worth.

18. Rodriguez-Lainz, A. J., Hird, D. W., Kass, P. H. and Brooks, D. L. 1997. Incidence and risk factors for bumblefoot (pododermatitis) in rehabilitated raptors. Prev. Vet. Med. 31: 175-184. [Medline] [CrossRef]

19. Rogers, K., Barrington, G. M. and Parish, S. M. 1997. Squamous cell carcinoma originating from a cutaneous scar in a llama. Can. Vet. J. 38: 643-644. [Medline]

20. The International Union for Conservation of Nature and Natural Resources (IUCN). Red List of Threatened Species Version 2020. https://www. iucnredlist.org [accessed on May 1, 2020].

21. Voiculescu, V., Calenic, B., Ghita, M., Lupu, M., Caruntu, A., Moraru, L., Voiculescu, S., Ion, A., Greabu, M., Ishkitiev, N. and Caruntu, C. 2016. From Normal Skin to Squamous Cell Carcinoma: A Quest for Novel Biomarkers. Dis. Markers 2016: 4517492. [Medline] [CrossRef] 